\title{
Originals
}

\section{Impact of Westernization on Carbohydrate and Lipid Metabolism in Australian Aborigines}

\author{
K.O'Dea ${ }^{1}$, R. M.Spargo ${ }^{2}$ and P.J. Nestel ${ }^{1}$ \\ ${ }^{1}$ Baker Medical Research Institute, Prahran, Victoria and ${ }^{2}$ Kimberley Health, Derby, Western Australia, Australia
}

\begin{abstract}
Summary. We have investigated plasma glucose and immunoreactive insulin responses to 75 -g oral glucose in lean, young, full-blood Aboriginal men from urban and rural communities and made comparisons with age- and weight-matched Caucasoids. Fasting glucose concentrations were lower in the rural Aborigines than in the urban Aborigines or the Caucasoids. Plasma glucose concentrations $2 \mathrm{~h}$ postprandially were significantly higher in both Aboriginal groups (urban $6.7 \pm 0.6 \mathrm{mmol} / 1$, rural $6.4 \pm$ $0.4 \mathrm{mmol} / 1)$ than in the Caucasoids $(5.0 \pm 0.3 \mathrm{mmol} /$ 1). Insulin responses in the two Aboriginal groups were almost identical and 50\% higher than in the Caucasoids. We also investigated glucose tolerance and plasma lipids in 67 full-blood Aborigines living in an isolated rural community. Only three people (two men and one woman) had diabetes while a further eight (six men and two women) had impaired glucose tolerance. Fasting plasma cholesterol concentrations did not increase with age and were significantly lower in the rural Aboriginal community than in either the urban Aborigines or the Caucasoids. These results suggest that elevations in fasting cholesterol and glucose concentrations are lifestyle-associated, but that mild impairment of glucose tolerance and high insulin response in the Aborigines may be inherited metabolic characteristics.
\end{abstract}

Key words: Australian Aborigines, diabetes, insulin secretion, glucose tolerance, traditional diet, urban diet, cholesterol, lipoproteins.

Epidemiological evidence suggests that Australian Aborigines are particularly susceptible to Type 2 (non-insulin-dependent) diabetes when they make a rapid transition from traditional to urban lifestyle.
Wise et al. $[1,2]$ surveyed a number of urbanized Aboriginal communities in South Australia and found a diabetes prevalence of $11 \%$. Bastian [3] reported a $17 \%$ prevalence among 'fringe-dweller' Aborigines of the West Kimberley whose lifestyle is characterized by poverty, high unemployment, high alcohol consumption and poor diet generally.

In a recent study of a small group of full-blood Aborigines, a marked reduction in plasma insulin concentration associated with a small improvement in glucose tolerance was observed upon reverting to traditional diet and increased physical activity [4]. The aim of the present study was to investigate the insulin response of two groups of lean, young Aboriginal men to oral glucose and to compare them with those of age- and weight-matched Caucasoids. The two groups of Aboriginal men came from the same geographical region in the north west of Australia but from communities with quite different lifestyles. One group, designated 'urban', had a lifestyle characterized by low physical activity and high consumption of alcohol, unenriched white flour and white sugar; while the other, designated 'rural', lived on a mission, was moderately physically active, had no access to alcohol and consumed a diet which contained fresh fruit, vegetables and meat daily, as well as white flour and sugar.

We have also attempted to study the frequency of diabetes and impaired glucose tolerance (IGT) in this less westernized rural Aboriginal community. Fasting plasma cholesterol and triglyceride concentrations were also measured in this group.

\section{Subjects and Methods}

Derby is the regional centre for the Kimberley in the north west of Australia. The Aboriginal population from which the subjects were drawn lived at the Mowanjum Community $15 \mathrm{~km}$ outside Derby. 
Table 1. Anthropometric data on the Aboriginal and Caucasoid men studied

\begin{tabular}{lllll}
\hline & $\begin{array}{l}\text { Age } \\
\text { (years) }\end{array}$ & $\begin{array}{l}\text { Height } \\
(\mathrm{cm})\end{array}$ & $\begin{array}{l}\text { Weight } \\
(\mathrm{kg})\end{array}$ & $\begin{array}{l}\text { aBody mass } \\
\text { index }\left(\mathrm{kg} / \mathrm{m}^{2}\right)\end{array}$ \\
\hline $\begin{array}{l}\text { Caucasoid } \\
(n=17)\end{array}$ & $21.7 \pm 0.8$ & $176.8 \pm 1.7$ & $67.7 \pm 2.1$ & $21.5 \pm 0.5$ \\
$\begin{array}{l}\text { Rural } \\
\text { Aborigines } \\
(n=15)\end{array}$ & $20.2 \pm 1.0$ & $174.4 \pm 2.2$ & $62.2 \pm 1.9$ & $21.1 \pm 0.7$ \\
$\begin{array}{l}\text { Urban } \\
\text { Aborigines } \\
(n=19)\end{array}$ & $23.0 \pm 1.2$ & $176.1 \pm 1.2$ & $66.2 \pm 2.6$ & $21.3 \pm 0.6$ \\
\hline
\end{tabular}

Results are expressed as mean \pm SEM

a Body mass index $=\frac{\text { weight }}{\text { height }^{2}}$

There were about 150 people over 15 years of age resident at Mowanjum at the time of the study. Alcohol consumption is generally high and has major deleterious consequences on overall nutrient intake: damper (unleavened bread made from white, unenriched flour) and extremely sweet tea (estimated to contain 20\%-30\% added sugar) being the main dietary staples. Their diet is therefore high in fat, alcohol and refined carbohydrates and relatively low in protein $(<10 \%)$.

In contrast, Kalumburu Benedictine Mission is situated on the northern coast of Western Australia, $750 \mathrm{~km}$ north east of Derby and is accessible by road for only $6-8$ months of the year. The people there lead a rural existence providing their supply of fruits, vegetables, bread, poultry, pigs and cattle. Beef and vegetable stew and rice is available twice each day. Soft drinks, sugar, breakfast cereals and canned food can be purchased from a store, but alcoholic drinks cannot be bought and are not allowed on the mission. In addition to the fixed population of about 160 Aborigines, Kalumburu has a transient population of relatives and friends.

\section{Comparison of Glucose Tolerance in Three Groups of Young Men}

The age, weight and body mass index of the subjects are shown in Table 1.

Urban Aborigines. Nineteen full-blood Aboriginal men (aged 15-35 years) participated in this study and represented about half of the total male population of this age in that community.

Rural Aborigines. Of the 17 full-blood Aboriginal men (aged 15-35 years) who were present at the time, 15 agreed to cooperate in the study. Ten participated in a glucose tolerance test and all $15 \mathrm{had}$ blood taken for plasma lipid concentrations.

Caucasoids. Seventeen white male volunteers from Melbourne were selected to match for age, height and weight with the Aboriginal groups.

\section{Survey of Diabetes and Impaired Glucose Tolerance in the Rural Aborigines at Kalumburu}

Of the 162 Aborigines from the Wunumbal tribal group who were registered officially as being resident at Kalumburu, 71 were under 15 years and not included. Of the target population of 91 people aged 15 years and over, 67 were surveyed. The 24 people not surveyed included seven who were over 60 years and 15 who were under 30 years (most of whom were absent at the time). There were no known diabetics among those not surveyed. All those studied were full-blood Aborigines.

\section{Procedures}

The investigation of the rural dwelling Aborigines was carried out over a 2-week period in August 1979. The main sources of carbohydrate in the rural diet were sugar, flour, rice, sweet potatoes, other vegetables and fruit, and carbonated drinks. Carbohydrate intake from these sources was assessed from a questionnaire and crosschecked with records of store purchases and food supplied from the kitchen and found to be $300-400 \mathrm{~g}$ per person per day. The main sources of carbohydrate in the urban diet were sugar, flour, rice, potatoes, carbonated drinks, sweet biscuits, sweetened condensed milk, beer and port. Carbohydrate intake from these sources was assessed by questionnaire to be $200-300$ g per person per day.

The three groups of men were studied after a 12 -h overnight fast. An indwelling IV cannula was inserted into a vein in the forearm and kept patent with a heparinized saline-filled syringe. A $75 \mathrm{~g}$ oral glucose tolerance test ('Glucola') was carried out with blood samples at $0,1 / 2,1,2$ and $4 \mathrm{~h}$.

The remaining Kalumburu residents had a simpler glucose tolerance test with blood samples before and $2 \mathrm{~h}$ after $75 \mathrm{~g}$ glucose after a 12 -h overnight fast.

\section{Analytical Methods}

Glucose concentrations were measured in fluoride oxalate plasma by the glucose oxidase method. Immunoreactive insulin concentrations in heparinized plasma were measured using dextran-coated charcoal for precipitation of free hormone after reaction of insulin with commercially available antiserum (Burroughs-Wellcome). Human insulin (Novo) was used as the standard. The range of the assay was 5-200 mU insulin $/ 1$ and the interassay coefficient of variation was $8 \%$. Fasting triglyceride concentrations were determined enzymatically after enzymatic hydrolysis using a Technicon autoanalyser. The normal range for triglyceride concentrations in fasting plasma was $0.5-2 \mathrm{mmol} / \mathrm{l}$. Total cholesterol concentration in fasting plasma was measured colorimetrically after reaction with acetic anhydride and concentrated sulphuric acid using a commercially available kit (Boehringer). The normal range for cholesterol concentration in fasting plasma from Caucasoids is $3.5-6.5 \mathrm{mmol} / \mathrm{l}$.

Cholesterol and triglyceride concentrations were also measured by automated enzymic techniques in very low density lipoproteins (VLDL) and in high density lipoproteins (HDL). VLDL were separated by $16-\mathrm{h}$ ultracentrifugation of plasma at $40,000 \mathrm{rev} /$ min in a Beckman L-50 centrifuge. HDL were separated from other plasma lipoproteins that had been precipitated by heparin-manganese chloride [5]. Lipids in low density lipoproteins (LDL) were calculated from the differences between whole plasma and VLDL + HDL.

\section{Diagnostic Criteria for Diabetes}

The criteria chosen for definition of diabetes were those of the US National Diabetes Data Group [6] for venous plasma glucose: fasting $\geq 7.8 \mathrm{mmol} / 1$ and $2 \cdot \mathrm{h}$ oral glucose tolerance test $>11.1 \mathrm{mmol} / 1$; impaired glucose tolerance: fasting $<7.8 \mathrm{mmol} / 1$ and $2 \mathrm{~h}$ oral glucose tolerance test between 7.8 and $11.1 \mathrm{mmol} / \mathrm{/}$; normal glucose tolerance: $2-\mathrm{h}$ oral glucose tolerance test $<7.8 \mathrm{mmol} / \mathrm{l}$.

\section{Statistical Methods}

Statistical analysis of the results was carried out using Student's $t$ test for unpaired data. The criterion for significance was a $p$ value $<0.05$. The areas under the curves for insulin and glucose were calculated using the trapezoidal rule. 
Table 2. The changes in plasma glucose and insulin concentrations in Caucasoid and Aboriginal men following $75 \mathrm{~g}$ oral glucose

\begin{tabular}{|c|c|c|c|c|c|}
\hline & Fasting & $30 \mathrm{~min}$ & $1 \mathrm{~h}$ & $2 \mathrm{~h}$ & $4 \mathrm{~h}$ \\
\hline \multicolumn{6}{|l|}{ Glucose $(\mathrm{mmol} / \mathrm{l})$} \\
\hline Caucasoid $(n=17)$ & $4.7 \pm 0.1$ & $7.9 \pm 0.4$ & $7.2 \pm 0.3$ & $5.0 \pm 0.3$ & $4.4 \pm 0.1$ \\
\hline Rural Aborigines $(n=15)$ & $4.1 \pm 0.2$ & $6.8 \pm 0.6$ & $7.1 \pm 0.4$ & $6.4 \pm 0.4$ & $4.4 \pm 0.3$ \\
\hline Urban Aborigines $(n=19)$ & $5.1 \pm 0.1$ & $7.3 \pm 0.3$ & $7.6 \pm 0.5$ & $6.7 \pm 0.5$ & $4.8 \pm 0.4$ \\
\hline \multicolumn{6}{|l|}{$\operatorname{Insulin}(m U / l)$} \\
\hline Caucasoid $(n=17)$ & $8.6 \pm 1.3$ & $51.5 \pm 5.7$ & $52.8 \pm 6.5$ & $26.3 \pm 3.3$ & $8.2 \pm 1.3$ \\
\hline Rural Aborigines $(n=15)$ & $11.2 \pm 0.9$ & $59.6 \pm 7.8$ & $68.5 \pm 8.4$ & $57.4 \pm 6.4$ & $11.7 \pm 2.8$ \\
\hline Urban Aborigines $(n=19)$ & $11.7 \pm 1.4$ & $59.9 \pm 5.7$ & $63.7 \pm 6.5$ & $53.8 \pm 7.9$ & $15.5 \pm 4.1$ \\
\hline
\end{tabular}

Results are expressed as mean \pm SEM

Statistical comparisons

Caucasoid $>$ rural Aboriginal: fasting glucose $(p<0.005)$

Urban Aboriginal $>$ rural Aboriginal: fasting glucose $(p<0.001)$

Urban Aboriginal $>$ Caucasoid: 2 h glucose $(p<0.01) 2 \mathrm{~h}$ insulin $(p<0.01)$

Rural Aboriginal $>$ Caucasoid: $2 \mathrm{~h}$ glucose $(p<0.005) 2 \mathrm{~h}$ insulin $(p<0.001)$

Table 3. Frequency of diabetes and impaired glucose tolerance among the Aborigines from Kalumburu

\begin{tabular}{|c|c|c|c|c|c|c|c|}
\hline & & $\begin{array}{l}\text { All } \\
\text { (yer }\end{array}$ & $\begin{array}{l}\text { ges } \\
\text { s) }\end{array}$ & $\begin{array}{l}15-3 \\
\text { year }\end{array}$ & & $>3$ & years \\
\hline \multirow[t]{2}{*}{$\begin{array}{l}\text { Number of } \\
\text { subjects }\end{array}$} & $\begin{array}{l}\text { (Total) } \\
\text { Male } \\
\text { Female }\end{array}$ & $\begin{array}{l}67 \\
31 \\
36\end{array}$ & & $\begin{array}{l}35 \\
15 \\
20\end{array}$ & & $\begin{array}{l}32 \\
16 \\
16\end{array}$ & \\
\hline & & No. & $\%$ & No. & $\%$ & No. & $\%$ \\
\hline \multirow[t]{3}{*}{ Diabetes } & (Total) & 3 & 4.5 & 0 & - & 3 & 9.4 \\
\hline & Male & 2 & 6.5 & 0 & - & 2 & 12.5 \\
\hline & Female & 1 & 2.8 & 0 & - & 1 & 6.3 \\
\hline \multirow{3}{*}{$\begin{array}{l}\text { Impaired } \\
\text { glucose } \\
\text { tolerance }\end{array}$} & (Total) & 8 & 11.9 & 3 & 8.6 & 5 & 15.6 \\
\hline & Male & 6 & 19.4 & 2 & 13.3 & 4 & 25.0 \\
\hline & Female & 2 & 5.6 & 1 & 5.0 & 1 & 6.3 \\
\hline
\end{tabular}

\section{Results}

\section{Comparison of Glucose Tolerance in Three Groups of Young Men}

Age and body mass index data of the men who participated in the study are presented in Table 1 . The body mass indices of the three groups were similar. The small differences in mean ages were not significant.

The change in plasma glucose in response to the glucose load is shown in Table 2. Fasting glucose concentrations were significantly lower in the rural Aborigines than in either the urban Aborigines or the Caucasoids. There were no significant intergroup differences 30 or $60 \mathrm{~min}$ after the glucose load. However, $2 \mathrm{~h}$ post-prandially, the plasma glucose concentration had returned to baseline in the Caucasoid group but remained significantly elevated $(p<0.01)$ in both Aboriginal groups in whom return to baseline occurred at $4 \mathrm{~h}$.
Plasma insulin response to the oral glucose load is also presented in Table 2. Basal insulin levels were similar in the three groups but subsequently insulin concentration tended to be lower in the Caucasoids than in either the rural or urban Aborigines (difference at $2 \mathrm{~h}, p<0.001$ ). The insulin responses in the two Aboriginal groups were similar, the areas under the insulin curves being almost identical (rural $182 \pm 21$, urban $179 \pm 22 \mathrm{mU}^{-1} \mathrm{~h}^{-1}$ ) but significantly greater than in the Caucasoids $\left(121 \pm 10 \mathrm{mU}^{-1} \mathrm{~h}^{-1}\right)$, $(p<0.02)$. The incremental increase in insulin concentration was highly correlated with the incremental increase in glucose concentration in all three groups $(p<0.01)$. Combining these results by comparing areas under the incremental glucose and insulin curves up to $2 \mathrm{~h}$ post-prandially for each group suggested that these correlations were stronger for the Aboriginal groups (Caucasoid NS, rural Aborigines $p<0.01$, urban Aborigines $p<0.01$ ).

\section{Survey of Glucose Tolerance and Diabetes in Kalumburu Population}

Many people aged 30-50 years live away from the mission resulting in an unusual pattern of age distribution. One-third of the population surveyed was over 50 years and one-half aged between 15 and 30 years. The mean body mass index of the women was $23.4 \pm 0.8 \mathrm{~kg} / \mathrm{m}^{2}$ and of the men $22.2 \pm 0.6 \mathrm{~kg} / \mathrm{m}^{2}$. There was a trend towards higher body mass index with increasing age.

Of the people 15 years and over who were tested, $83.6 \%$ had normal glucose tolerance, $11.9 \%$ had impaired glucose tolerance and $4.5 \%$ had diabetes (Table 3). No-one under 54 years of age had diabetes. Proportionately more men than women were glucose intolerant. 
Table 4. Plasma lipoprotein lipid composition in Aboriginal and Caucasoid men $<35$ years and plasma cholesterol and triglyceride concentrations in the rural Aboriginal population surveyed

\begin{tabular}{|c|c|c|c|c|c|c|}
\hline & \multirow{3}{*}{$\begin{array}{l}\text { Caucasoids } \\
\text { Men } \\
<35 \text { years }\end{array}$} & \multicolumn{5}{|l|}{ Aborigines } \\
\hline & & \multirow{2}{*}{$\begin{array}{l}\text { Urban } \\
\text { Men } \\
<35 \text { years }\end{array}$} & \multicolumn{4}{|l|}{ Rural } \\
\hline & & & $\begin{array}{l}\text { Men } \\
<35 \text { years }\end{array}$ & $\begin{array}{l}\text { Women } \\
<35 \text { years }\end{array}$ & $\begin{array}{l}\text { Men } \\
>35 \text { years }\end{array}$ & $\begin{array}{l}\text { Women } \\
>35 \text { years }\end{array}$ \\
\hline Number of subjects & 11 & 19 & 15 & 21 & 16 & 15 \\
\hline \multicolumn{7}{|l|}{ Plasma } \\
\hline Cholesterol $(\mathrm{mmol} / \mathrm{l})$ & $4.89 \pm 0.29$ & $5.00 \pm 0.09$ & $3.89 \pm 0.27$ & $3.28 \pm 0.17$ & $3.67 \pm 0.22$ & $3.53 \pm 0.23$ \\
\hline Triglyceride $(\mathrm{mmol} / \mathrm{l})$ & $1.20 \pm 0.19$ & $1.86 \pm 0.29$ & $1.73 \pm 0.38$ & $0.83 \pm 0.08$ & $1.61 \pm 0.29$ & $1.23 \pm 0.24$ \\
\hline \multicolumn{7}{|l|}{ HDL } \\
\hline Cholesterol $(\mathrm{mmol} / \mathrm{l})$ & $1.14 \pm 0.12$ & $1.17 \pm 0.09$ & $0.85 \pm 0.04$ & & & \\
\hline Triglyceride (mmol/l) & $0.60 \pm 0.11$ & $0.42 \pm 0.06$ & $0.56 \pm 0.10$ & & & \\
\hline \multicolumn{7}{|l|}{ VLDL } \\
\hline Cholesterol $(\mathrm{mmol} / \mathrm{l})$ & $0.19 \pm 0.05$ & $0.49 \pm 0.10$ & $0.57 \pm 0.17$ & & & \\
\hline Triglyceride $(\mathrm{mmol} / \mathrm{l})$ & $0.10 \pm 0.04$ & $0.50 \pm 0.13$ & $0.46 \pm 0.22$ & & & \\
\hline \multicolumn{7}{|l|}{$\mathrm{LDL}$} \\
\hline Cholesterol $(\mathrm{mmol} / \mathrm{l})$ & $3.61 \pm 0.36$ & $3.34 \pm 0.23$ & $2.46 \pm 0.16$ & & & \\
\hline Triglyceride $(\mathrm{mmol} / \mathrm{l})$ & $0.45 \pm 0.09$ & $0.95 \pm 0.12$ & $0.70 \pm 0.08$ & & & \\
\hline
\end{tabular}

Results expressed as mean $\pm \mathrm{SEM}$

Statistical comparisons

Men

Urban Aboriginal > rural Aboriginal: HDL cholesterol $(p<0.05)$ LDL cholesterol $(p<0.05)$

Urban Aboriginal > Caucasoid: VLDL cholesterol $(p<0.02)$ VLDL triglyceride $(p<0.01)$ LDL triglyceride $(p<0.005)$

Caucasoid $>$ rural Aboriginal: Total cholesterol $(p<0.02)$ HDL cholesterol $(p<0.05)$ LDL cholesterol $(p<0.001)$

Rural Aboriginal $>$ Caucasoid: VLDL cholesterol $(p<0.05)$

Rural Aboriginal men versus women

Men under 35 years $>$ women under 35 years: plasma trigylceride $(p<0.01)$

\section{Plasma Lipid and Lipoprotein Values}

Total plasma cholesterol concentrations in rural Aborigines were significantly lower than in either the urban Aborigines or Caucasoids (Table 4). Both HDL and LDL cholesterol contributed to the difference. Total triglyceride concentrations tended to be higher, though not significantly, in the Aboriginal groups. However, triglyceride concentrations in VLDL and LDL were both significantly higher in the urban Aborigines than in the Caucasoids, and the rural Aborigines also had higher VLDL cholesterol than the Caucasoids. Table 4 also shows the plasma lipid data for all Kalumburu residents tested. Men aged under 35 years had significantly higher triglyceride levels than the women $(p<0.01)$. Plasma cholesterol concentrations were similar in men and women and low in comparison with Caucasoids.

\section{Discussion}

Despite close similarities in age distribution and leanness of the three groups under study, there were striking differences in glucose tolerance and insulin responses between the Caucasoid and Aboriginal men. The two Aboriginal groups resembled each other closely in terms of glucose tolerance and insulin response to oral glucose, although the Kalumburu (rural) men had significantly lower fasting glucose concentrations.

Both Aboriginal groups exhibited impairment of glucose tolerance characterized by mildly elevated plasma glucose levels $2 \mathrm{~h}$ after a $75 \mathrm{~g}$ oral glucose load. By contrast, the Caucasoid group had regained basal glucose levels at this time. This degree of impairment of glucose tolerance has been recently reported to be associated with doubling of the risk of mortality from coronary heart disease in the large Whitehall study of British male civil servants [7].

Although the three groups had similar basal insulin levels, the glucose-stimulated insulin response was significantly higher in the Aboriginal groups than in the Caucasoids. The strong correlations between incremental insulin and glucose levels observed in this study are consistent with previous findings $[8,9]$ in which increased insulin responses were associated with mild impairment of glucose tolerance. As the degree of impairment of glucose tolerance progressed to diabetes, however, the insulin response fell off. The lack of difference between the two Aboriginal groups, despite major differences in lifestyle, suggests that a high insulin secretory response may be a metabolic characteristic of these people. Indeed previous stud- 
ies on a group of Aborigines from the same area indicated that they exhibited unusually high insulin responses both in the urban environment and after reverting temporarily to their traditional hunter-gatherer lifestyle [4].

High insulin responses have been demonstrated in other populations when they make a rapid transition from traditional to urban life. Examples of such populations include the Pima Indians [10, 11], Polynesians, Micronesians [12,13] and Melanesians [14]. In addition to being associated with increased risk of Type 2 diabetes, high plasma insulin levels have also been shown to be associated with increased risk of coronary heart disease in three prospective population studies [15-17]. In these studies the plasma insulin level was of better predictive value than blood glucose and was independent of other coronary heart disease risk factors. Whether or not the mild impairment of glucose tolerance and hyperinsulinaemia observed in these people will be associated with increased risk of coronary heart disease remains to be seen. In this context however it is of interest to note that Bastian [3] and Wise et al. [2] have reported much higher prevalence rates for coronary heart disease in their Aboriginal populations than have been reported for white Australians in the Busselton Survey [18].

In view of the rural-urban differences in diabetes prevalence rates which have been reported for other populations (e.g. Western Samoa [19] and New Guinea [14], it seems reasonable to suggest that the lower frequency of diabetes observed in this rural Aboriginal community in comparison with those reported for urbanized Aboriginal communities [2, 3] reflects a similar phenomenon, despite the different diagnostic criteria employed and the small sample size. These data, together with the more detailed metabolic studies on the lean young Aboriginal men from the urban and rural communities, suggest that both groups have the metabolic characteristics which would predispose them to Type 2 diabetes [6], but whether or not they develop diabetes in later life would depend upon their environment.

The rural Aborigines had significantly lower total plasma, LDL and HDL cholesterol concentrations than either the urban Aborigines or the Caucasoids. Furthermore, total plasma cholesterol did not increase with age in the rural population. This has been reported in several other non-urbanized, non-Caucasoid populations $[20,21]$ as well as in vegetarians [22]. HDL cholesterol levels are generally low if the total plasma cholesterol is unusually low [23]. The few reports of serum lipids in Australian Aborigines have shown fairly similar levels as in Caucasoids [2, 3, 24]. The higher plasma and lipoprotein triglyceride levels in both groups of Aboriginal men may have resulted from their hyperinsulinaemia which has been shown to stimulate triglyceride production in man [25].

Acknowledgements. We are greatly indebted to the people of the Mowanjum Community in Derby and the Kalumburu Aboriginal Community who, through their invaluable help and cooperation, made this study possible. The help and collaboration of Sister Josephine Montero of the Kalumburu Mission and all at Community Health Services in Derby, Wyndham and Perth, who facilitated the smooth progression of this work, is also appreciated. We would like to thank L. Antonoff and D. Falkner for their expert technical assistance. Ames Pharmaceuticals generously donated the 'Glucola' and assisted with the transport of supplies to and from the field. Their help is gratefully acknowledged. This work was supported by a grant from the National Health and Medical Research Council of Australia.

\section{References}

1. Wise PH, Edwards FM, Thomas DW, Elliot RB, Hatcher L, Craig R (1970) Hyperglycemia in the urbanized Aboriginal. Med J Aust 2: 1001-1006

2. Wise PH, Edwards FM, Craig RF, Evans B, Murchland JB, Sutherland B, Thomas DW (1976) Diabetes and associated variables in the South Australian Aborigines. Aust NZ J Med 6: 191-196

3. Bastian P (1979) Coronary heart disease in tribal Aborigines the West Kimberley Survey. Aust NZ J Med 9: 284-292

4. O'Dea K, Spargo RM, Akerman K (1980) The effect of transition from traditional to western lifestyle on the insulin secretory response in Australian Aborigines. Diabetes Care 3:31-37

5. Albers JJ, Warnick GH, Cheung MC (1978) High density lipoprotein quantitation. Lipids 13:926-932

6. National Diabetes Data Group (1979) Classification and diagnosis of diabetes mellitus and other categories of glucose intolerance. Diabetes 28: 1039-1057

7. Fuller JH, Shipley MF, Rose G, Jarrett RJ, Keen H (1980) Coronary heart disease risk and impaired glucose tolerance. The Whitehall study. Lancet 1 : 1373-1376

8. Reaven G, Miller R (1970) Study of the relationship between glucose and insulin responses to an oral glucose load in man. Diabetes 17:560-569

9. Savage PJ, Dippe SE, Bennett PH, Gorden P, Roth J, Rushforth NB, Miller M (1974) Hyperinsulinemia and hypoinsulinemia. Insulin responses to oral carbohydrate over a wide spectrum of glucose tolerance. Diabetes 24:362-368

10. Bennett PH, Burch TA, Miller M (1971) Diabetes mellitus in American (Pima) Indians. Lancet ii: 125-128

11. Aronoff SL, Bennett PH, Gorden P, Rushforth N, Miller M (1977) Unexplained hyperinsulinemia in normal and "prediabetic" Pima Indians compared with normal Causasians. Diabetes $26: 827-840$

12. Zimmet P, Taft G, Guinea A, Guthrie W, Thoma K (1977) The high prevalence of diabetes mellitus on a central Pacific island. Diabetologia 13:111-115

13. Zimmet P, Whitehouse S, Kiss J (1979) Ethnic variability in the plasma insulin response to oral glucose in Polynesian and Micronesian subjects. Diabetes 28: 624-628

14. Martin FIR, Wyatt GB, Griew AR, Haurahelia M, Higginbotham $L(1980)$ Diabetes mellitus in urban and rural communities in Papua New Guinea. Studies of prevalence and plasma insulin. Diabetologia 18: 369-374

15. Pyörälä K (1979) Relationship of glucose tolerance and plasma insulin to the incidence of coronary heart disease: results from two population studies in Finland. Diabetes Care 2: 131-141 
16. Welborn TA, Wearne K (1979) Coronary heart disease incidence and cardiovascular mortality in Busselton with reference to glucose and insulin concentrations. Diabetes Care 2: 154-160

17. Ducimetiere P, Eschwege E, Papoz L, Richard JL, Claude JR, Rosselin G (1980) Relationship of plasma insulin levels to the incidence of myocardial infarction and coronary heart disease mortality in a middle-aged population. Diabetologia 19: 205-210

18. Welborn TA, Cumpston GN, Cullen KJ, Curnow DH, McCall MG, Stenhouse NS (1969) The prevalence of coronary heart disease and associated factors in an Australian rural community. Am J Epidemiol 89: 521-536

19. Zimmet P, Faaivso S, Ainvu J, Whitehouse S, Milne B, De Boer W (1981) The prevalence of diabetes in the rural and urban Polynesian populations of Western Samoa. Diabetes 30: $45-51$

20. Connor WE, Cerqueira MT, Connor RW, Wallace RB, Malinow MR, Cadorph HR (1978) The plasma lipid lipoproteins and diet of the Tarahumara Indians of Mexico. Am J Clin Nutr $31: 1131-1142$

21. Nestel PJ, Zimmet P (1981) HDL levels in Pacific islanders. Atherosclerosis 40:257-262
22. Burslem J, Schonfeld G, Howald MA, Weidman SW, Miller JP (1978) Plasma apoprotein in lipoprotein lipid levels in vegetarians. Metabolism 27:711-719

23. Heiss G, Tyroler H (1979) Epidemiology of high density lipoprotein: A review. In: Lippel K(ed) A report of the high density lipoprotein methodology workship. Publication no 79-1661, NIH, Washington, pp 7-27

24. Schwartz CJ, Caseley-Smith JR (1958) Serum cholesterol levels in atherosclerotic subjects and in the Australian Aborigines. Med J Aust 2: 84-86

25. Tobey TA, Greenfield M, Kraemer F, Reaven GM(1981) Relationship between insulin resistance, insulin secretion, very low density lipoprotein kinetics and plasma triglyceride levels in normotriglyceridemic man. Metabolism 30: 165-171

Received: 14 April 1981

and in revised form: 24 August 1981

Dr. Kerin O'Dea

Baker Medical Research Institute

Commercial Road

Prahran, Victoria 3181, Australia 